\section{Management of Chronic Hepatitis B: New Stopping Rules}

\section{Abstract}

Chronic hepatitis B (CHB) treatment is limited by the availability of antiviral agents and the variable response to those agents. Currently, the only approved antiviral agents are Pegylated interferon and nucleos(t)ide analogues. The response to these therapies varies widely between CHB patients. Thus, the patients with non-favorable response are ultimately exposed to unnecessary side effects and costs. All current guidelines provide information regarding the time to initiate therapy. However, a clear consensus regarding the predictors of non response and consequently terminating the treatment is still lacking. Many studies that determine the adequacy of the use of predictive markers early in the course of the disease will be reviewed here. During Pegylated interferon therapy, combination of decline in serum HBV DNA and $\mathrm{HBs} A g$ levels from baseline at week 12 could generate a solid stopping rule. Using nucleos(t)ide analogues in chronic HBeAg-positive patients, the on-treatment HBsAg quantitation at 6 months appears to have a useful role in determining the duration of therapy in patients who achieve HBeAg loss (or seroconversion) during treatment. In chronic HBeAg-negative patients, the Asian Pacific Association for the Study of Liver (APASL) stopping rules are adequate with proper off-therapy monitoring. Furthermore, the durability of off-therapy response for both classes based on long term follow-up studies will be discussed here. Through this review we will present a clear generation of stopping rules to guide the antiviral therapy early enough to predict non response and shift to other agents. Therefore, adopting a costeffective approach in the treatment of chronic hepatitis B.

\section{Background}

Hepatitis B virus (HBV) infection is a major and global health problem. Approximately one third of the world's population has serological evidence of past or present infection with HBV and 350-400 million people are chronic HBV surface antigen (HBsAg) carriers [1, 2]. As the course of chronic hepatitis $B(C H B)$ depends strongly on
Malak Noureddine', lyad Issa1, Rami Moucari²

1 Rafik Hariri University Hospital, Dept of Gastroenterology \& Hepatology, Beirut, Lebanon

2 Advanced Cure Diagnostic Center, Dept of Gastroenterology \& Hepatology, Abu Dhabi, United Arab Emirates.

\section{Contact information:}

lyad Issa.

Address: Specialty Clinics Center 4B, Hamra, Maamari Strt. Postal code: 20347304. Beirut, Lebanon.

$\equiv$ lyadissa71@gmail.com 
the interplay between the virus and the host, the spectrum of disease and natural history of chronic HBV infection are diverse and variable, ranging from an inactive carrier state to progressive CHB in both forms (HBeAg-positive and HBeAg-negative), which may evolve to cirrhosis and hepatocellular carcinoma (HCC) $[1,2,3]$.

The clinical outcome in patients with $\mathrm{CHB}$ has shown significant advance with the introduction of nucleos ( $\mathrm{t}$ ) ide analogues (NUCs) as an oral antiviral therapy. Current international guidelines for the management of $\mathrm{CHB}$ provide adequate information regarding the start of the antiviral therapy. However, there is no clear consensus on early prediction of the response and thus using this to decide when to stop treatment.

In this review, we discuss the durability of offtherapy response as well as the predictors of response to different classes of antiviral therapy in both chronic hepatitis B e antigen ( $\mathrm{HBeAg}$ ) negative and positive patients in an attempt to generate an algorithm on when to stop the treatment early in the course of the disease and consider shifting to a different class of therapy.

\section{HBV life cycle}

The reverse transcription of pregenomic RNA (pgRNA), which is an RNA intermediate copy of the 3.2-kb DNA genome, constitutes the most important step in the HBV life cycle. This replication cycle involves multiple complex steps that start with attachment, penetration, and uncoating of the hepatitis $B$ virus (HBV) virions. These steps lead to the internalization of the covalently closed circular DNA (cccDNA) into the host's nucleus which is responsible for the persistent infection of hepatocytes. This is followed by viral assembly and release of the progeny virions [4-6].

\section{Hepatitis B: Natural history}

There are three chronological phases in the natural course of chronic hepatitis $B$ infection (CHB). In the immune-tolerance phase patients are positive for $\mathrm{HBeAg}$, have normal alanine aminotransferase (ALT) level with elevated HBV DNA, and absence or minimal liver inflammation. Then comes the immuneclearance phase when HBeAg-positive patients have elevated ALT level with active liver inflammation. Finally, reaching the inactive residual phase in which HBeAg seroconversion to its antibody occurs with ALT normalization, low or undetectable HBV DNA, and improvement of liver inflammation with time, which could occur in the majority of inactive carriers [7-9]. However, up to $25 \%$ of them may have reactivation of HBV with replication and exacerbation of hepatitis [8,9], and some of the inactive carriers will finally lose HBsAg but with persistent low level of HBV replication in the liver [7, 10].

Serum HBsAg appears to correlate with the presence of cccDNA and is considered a surrogate marker of infected cells. Seroclearance of HBsAg is the closest event to a cure from HBV infection and is the main goal of CHB therapy. However, loss of HBsAg before the onset of cirrhosis is associated with a more favorable outcome; that is, a lower risk of cirrhosis, decompensation, and HCC.

\section{Inactive Carrier State}

The goal of any antiviral therapy is to reach the state of low HBV DNA and HBsAg levels, which designates the decrease in the number of infected cells and the level of replication within them. For instance, a cohort of 70 Caucasian patients with $\mathrm{HBeAg}$-positive $\mathrm{CHB}$ at presentation were followed up to 25 years to assess the risk factors for liverrelated death which occurred in $15.7 \%$ of them. The 25 -year survival probability was $95 \%$ in inactive carriers, 50\% in patients with $\mathrm{HBeAg}$-negative $\mathrm{CHB}$ or $\mathrm{HBeAg}$ reversion, and $40 \%$ in patients persistently HBeAg-positive [11].

The inactive carrier state occurs in $67 \%$ to $80 \%$ of carriers after spontaneous HBeAg seroconversion [12]. Approximately $4 \%$ to $20 \%$ of inactive carriers have $\mathrm{HBeAg}$ reversion. $10 \%$ to $30 \%$ of those who 
remain anti-HBe positive after $\mathrm{HBeAg}$ seroconversion continue to have elevated ALT and high HBV DNA level, and roughly $10 \%$ to $20 \%$ of inactive carriers may encounter HBV reactivation and progress to HBeAg-negative chronic hepatitis after years of inactiveness [12]. Thus, to confirm if an HBsAg positive, $\mathrm{HBeAg}$-negative carrier is maintained in the inactive carrier state a lifelong follow-up with ALT level at least every 3-4 months during the first year then every 6 months and periodical measurements of HBV DNA level is necessary $[12,13]$.

The accurate identification of inactive HBV carriers is a difficult task because of the wide and frequent HBV DNA fluctuations. A study including 209 untreated HBeAg-negative genotype D asymptomatic carriers followed-up prospectively found that single point combined quantification of HBsAg $<1000 \mathrm{IU} / \mathrm{ml}$ and HBV DNA $<2000 \mathrm{IU} / \mathrm{ml}$ provides the most precise identification of an inactive carrier state, comparable to that of long term tight monitoring with a diagnostic accuracy of $>90 \%$, negative predictive value (NPV) of $96-97 \%$, and positive predictive value (PPV) of $84-87 \%$ [14, 15]. Therefore, active $\mathrm{CHB}$ can be distinguished from inactive carriers with low risk of progression to cirrhosis and HCC who will not consequently need to be treated.

\section{Treatment Options in Chronic Hepatitis B Patients}

Left untreated, chronic HBV patients will ultimately progress to cirrhosis, end-stage liver disease, HCC and death [13]. The prevention of this progression leads to the improvement in the quality of life and survival of CHB patients, which can be attained if HBV replication is repressed with an effective therapy. Clearing HBsAg from the serum is the ideal endresult, which is rarely achievable with the currently available anti-HBV agents. A more realistic endpoint is the induction of sustained or maintained virological remission.

Over the last 20 years, 2 interferon (IFN)-based therapies, with dual direct antiviral but nonspecific effect and immunomodulation properties, and 5 oral nucleos(t)ide analogues, all of which are HBV life cycle inhibitors resulting in maintained remission with no immune control, have been approved by the United States Food and Drug Administration (FDA) for the treatment of CHB. These agents include IFN, pegylated IFN, lamivudine (LMV), adefovir dipivoxil (ADV), entecavir, telbivudine, and tenofovir disoproxil fumarate (TDF).

\section{Interferon therapy}

Chronic hepatitis B is an immune-based disorder in which the extent of disease as well as the frequency and quality of virologic response are profoundly influenced by the strength of the host immunologic response. Therefore, all of the international practice guidelines advocate IFN or peg IFN as potential first-line therapy for both HBeAg-positive and HBeAg-negative patients. This is based on the immunomodulatory properties of peg interferon, and its efficacy to restore the host immune control on HBV replication, resulting in sustained disease remission in a proportion of patients after a finite course of therapy. A major hindrance to the use of peg interferon is its lack of effectiveness in a large proportion of patients. In this respect, international practice guidelines do not specifically advocate its use as being primary. Previous studies have tried to circumvent this shortcoming to a certain extent by the use of response predictor models based on pretreatment host and viral factors such as age, gender, serum alanine aminotransferase (ALT) level, serum HBV DNA level, and HBV genotype. All of these parameters have been independently associated with SVR in multivariate analyses. However, their predictive values (odds ratio) were not powerful. Regardless of patient baseline characteristics, it is also worthwhile for physicians to determine in the early phase of treatment with peg interferon, which patient is less likely to develop SVR and should thus discontinue or consider alternative treatments ('stopping rule'). 


\section{Interferon Therapy in Chronic HBeAg- negative Patients}

The efficacy and safety of peg interferon alfa-2a

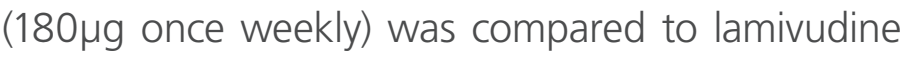
(100mg daily) alone or in combination with peg interferon alfa-2a in a total of 537 HBeAg-negative CHB patients treated for 48 weeks and followed for an additional 24 weeks. This study showed significantly higher rates of sustained response for 24 weeks after the cessation of therapy in patients treated with peg interferon alfa-2a than with lamivudine [16]. Post study follow-up revealed that of the $230 \mathrm{HBeAg}$-negative patients treated with peg interferon alfa-2a, 31\% had HBV DNA $\leq 10,000 \mathrm{cp} /$ $\mathrm{ml} 1$-year after end of treatment and in these 50\% had sustained suppression at year 5 post treatment $[17,18]$.

In a randomized, placebo-controlled study, Brunetto et al analyzed the correlation between hepatitis B virus surface antigen (HBsAg) serum level decline and post treatment response in $386 \mathrm{HBeAg}$ negative $\mathrm{CHB}$ patients treated with pegylated interferon alfa-2a, with or without lamivudine, versus lamivudine alone. This study revealed that the amount of HBsAg decline from pretreatment to week 48 was approximately 30 times higher with peg interferon alfa-2a (alone or in combination with lamivudine) versus lamivudine alone (mean declines of -0.71 and $-0.67 \log _{10} \mathrm{IU} / \mathrm{ml}$, respectively, versus $-0.02 \log _{10} \mathrm{IU} / \mathrm{ml}$ in patients treated with lamivudine monotherapy; $P<0.01)$. In the sub-group of patients treated with peg interferon alfa-2a-based therapy, those who achieved a virological response had a greater mean decline in HBsAg from pretreatment levels to week 48 than those who did not. The mean HBsAg decline was $-1.077 \log _{10}$ for the HBV DNA $\leq 400$ copies/ml endpoint responders versus -0.263 for nonresponders $(P<0.001)$. In this group in particular, there was a strong association between end of treatment HBsAg level and suppression of HBV DNA to $\leq 400$ copies $/ \mathrm{ml}$. This suppression was maintained 6 months post treatment in a very high proportion of peg interferon alfa-2a treated patients with end of treatment HBsAg level $\leq 10 \mathrm{lU} /$ $\mathrm{ml}$. Moreover, the absolute HBsAg level of $\leq 380$ $\mathrm{IU} / \mathrm{ml}$ at week 48 or a change in HBsAg level from pretreatment to week 48 of $>1.87 \log _{10} \mathrm{IU} / \mathrm{ml}$ were considered to be the best predictive values for fore-seeing HBsAg clearance 3 years after treatment. HBsAg $\leq 19 \mathrm{lU} / \mathrm{ml}$ at week 48 and an on-treatment reduction in $\mathrm{HBsAg}$ of $>0.46 \log _{10} \mathrm{IU} / \mathrm{ml}$ were considered the cut-off levels associated with reduction in HBV DNA level to $\leq 400$ copies/ml 3 years after treatment. These results showed that HBsAg level decline during therapy with peg interferon alfa-2a may help identify those subjects likely to be cured by this therapy and thus can be used as a potential marker of non response and consequently considering switching the patient to another regimen [19].

In peg interferon alfa-2a \pm lamivudine-treated patients, Marcellin et al. compared the decline in HBsAg level in virological responders (HBV DNA $\leq 2,000 \mathrm{lU} / \mathrm{ml}$ at the end of treatment and 5 years post-treatment) with that in relapsers (response at end treatment that was not sustained until year 5) and in non-responders (HBV DNA $>2,000 \mathrm{IU} / \mathrm{ml}$ at the end of treatment and 5 years post treatment) using 10\% $\log _{10}$ decline from baseline as a cut-off at weeks 12 and 24 . Those with $a \geq 10 \% \log _{10} \mathrm{HBsAg}$ decline from baseline established significantly higher rates of HBV DNA $\leq 2,000 \mathrm{lU} / \mathrm{ml}$ at both year 1 and 5 post treatment than patients with a $<10 \% \log _{10}$ decline from baseline. Applying the above mentioned cut-off level at weeks 12 and 24 achieved a PPV of 47 and $43 \%$, respectively, and NPVs of 84 and $87 \%$, respectively, at year 1 . At year 5, PPVs were 42 and $36 \%$, and NPVs were $87 \%$ at both weeks 12 and 24 . HBsAg clearance was more pronounced in responders than in relapsers and non-responders. On-treatment HBV DNA level did not discriminate between responders and relapsers in either peg interferon alfa-2a treatment groups [18].

Moreover, Moucari et al studied the relationship between on-treatment serum HBsAg kinetics 
and the prediction of sustained virological response (SVR) in $48 \mathrm{HBeAg}$ negative CHB patients treated with peg interferon for 48 weeks. During treatment, a marked decrease in serum HBsAg was shown in patients who developed SVR, with a mean decreases of $0.8 \pm 0.5 \log _{10} \mathrm{IU} / \mathrm{ml}, 1.5 \pm 0.6 \log _{10} \mathrm{IU} / \mathrm{ml}$, and $2.1 \pm 1.2 \log _{10} \mathrm{IU} / \mathrm{ml}$ at weeks 12, 24, and 48, respectively. By contrast, in patients who failed to achieve SVR serum HBsAg level did not decrease during treatment, particularly in non-responders. However, a slight later on-treatment decline but also a slow continuing off treatment decline of serum HBsAg was observed in relapsers. Furthermore, the cut-off of $0.5 \log _{10} \mathrm{IU} / \mathrm{ml}$ decrease at week 12 had a PPV of $89 \%$ and a NPV of $90 \%$. At week 24 , the cut-off of $1 \log _{10} \mathrm{IU} / \mathrm{ml}$ decrease had a PPV of $92 \%$ and a NPV of $97 \%$. Another major finding in sustained responders was the high rate of HBsAg loss. Interestingly, patients continued to decrease their serum HBsAg level post treatment cessation after developing SVR even without HBsAg loss [20].

In an additional trail, Rijckborst et al also analyzed the role of early on-treatment serum HBsAg level in achieving a sustained response in $107 \mathrm{HBeAg}$ negative patients receiving peg interferon alfa-2a. None of the 20 patients in whom a decrease in serum HBsAg level was absent and whose HBV DNA level declined less than 2 log copies/ml ex- hibited an SR (NPV=100\%), thus allowing the best prediction of SR by combining the declines in both levels at week 12 . Consequently, therapy could be discontinued without a loss of sustained responders $[13,21]$. Thus, in HBeAg-negative patients on treatment with PEG-IFN combining decline in HBV DNA and HBsAg levels suggested a solid stopping rule, enabling on-treatment adjustments. This rule was also validated in another study including 102 HBeAg-negative patients infected with all four major HBV genotypes (A-D), receiving 48 or 96 weeks of PEG-IFN, but its performance was best in those infected with genotype D (Figure 1). Eventually, avoiding unnecessary treatment by the application of this early stopping rule may thus optimize the cost-effectiveness of PEG-IFN therapy [13, 22].

\section{Interferon therapy in chronic HBeAg- positive patients}

The main goal of therapy for HBeAg-positive chronic hepatitis B patients is HBeAg seroconversion, since it is associated with improved long term clinical outcomes, such as increased complications-free and overall survival $[23,24]$.

The efficacy and safety of peg interferon alfa-2a was compared to lamivudine alone or in combination with peg interferon alfa-2a in a total of 814 HBeAg-positive CHB patients treated for 48 weeks and followed for an additional 24 weeks. It showed

Figure 1: Second stopping rule: PEG-IFN in HBeAg-negative patients.

Week 12

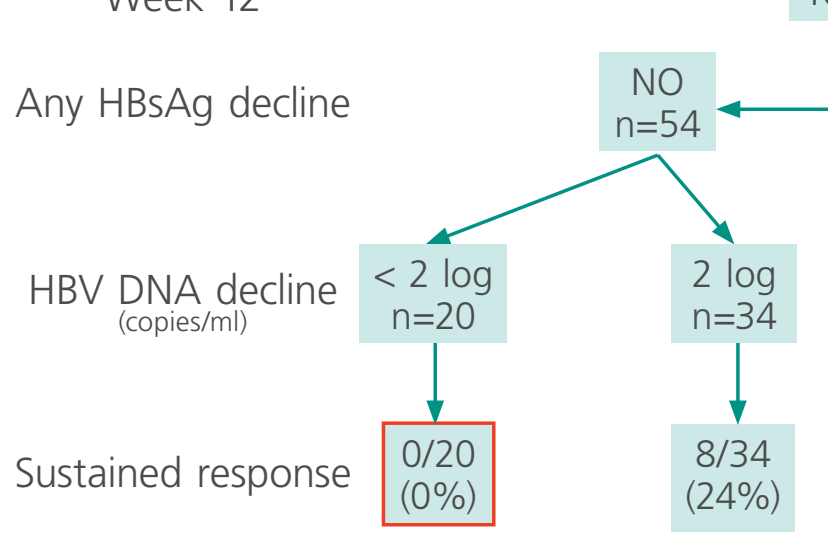

102 patients

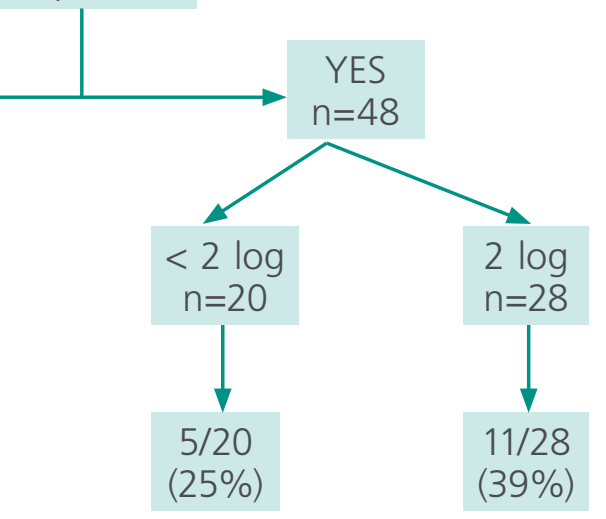


that the percentage of patients with HBeAg seroconversion was highest with peg interferon alfa-2a monotherapy (27\%) at the end of treatment, which continue to rise during the entire study period reaching $32 \%$ and $42 \%$ at 6 months and 1 year post treatment respectively [25].

Liaw et al. performed another study comparing the efficacy and safety of either a 24 or 48 weeks' protocol and a $90 \mu \mathrm{g} /$ week or $180 \mu \mathrm{g} /$ week doses in $544 \mathrm{HBeAg}$-positive patients treated with PEGIFN alpha-2a. The highest $\mathrm{HBeAg}$ seroconversion rates 6 months post treatment (36.2\%) were seen in the licensed regimen of PEG-IFN alpha-2a (180 $\mu \mathrm{g} /$ week for 48 weeks) which was the most efficacious and beneficial compared to lower doses and shorted durations [26].

Buster et al. investigated the durability of response to PEG-IFN alpha-2b (100 $\mu \mathrm{g} /$ week $) \pm$ lamivudine (100 mg/day) for 52 weeks in 266 HBeAg-positive chronic hepatitis $B$ patients. This study showed that $58 \%$ of initial responders had an HBV DNA level $<400$ copies/ml at long term follow up, and $45 \%$ of them had an HBV DNA level $<400$ copies $/ \mathrm{ml}$. Furthermore, among the 64 initial responders, 81\% had negative $\mathrm{HBeAg}, 30 \%$ had negative $\mathrm{HBsAg}$, and $77 \%$ had a normal ALT level at long term follow up. Overall, $11 \%$ had a negative HBsAg in the long term follow-up study [27].

Sonneveld et al. evaluated the early predictive role of on-treatment HBsAg level to determine the response to PEG-IFN in $803 \mathrm{HBeAg}$-positive $\mathrm{CHB}$ patients. This trail showed that individualizing treatment could be aided by the quantification of HBsAg. At week 12, PEG-IFN non-responders could be identified if the HBsAg level $>20,000 \mathrm{IU} / \mathrm{ml}$ as well as the absence of a decline from baseline, but the differences in performance across HBV genotypes warrant careful application. At week 24, PEGIFN discontinuation is indicated in all patients with HBsAg level > 20,000 IU/ml, since they have a low probability of response, irrespective of HBV genotype $[13,28]$.
Moreover, Liaw et al. did show that patients treated with 48 weeks of PEG-IFN $\alpha$-2a were unlikely to achieve sustained response if at week 12 and 24 their HBsAg level $>20,000 \mathrm{IU} / \mathrm{ml}$ with a NPV of $100 \%$ [26].

Heijtink et al. evaluated the role of serum $\mathrm{HBeAg}$ quantitation during interferon treatment in $30 \mathrm{HBeAg}$-positive CHB patients. This study concluded that the change in HBeAg level at week 4 and 8 of interferon therapy may have a significant clinical role in early identification of nonresponders [29].

In another trail, Tangkijvanich et al. compared between the clinical importance of quantitative serum HBsAg, HBeAg, and HBV DNA for predicting virological response to PEG-IFN therapy in 30 HBeAg-positive CHB patients. They concluded that on-treatment dynamic quantitation of serum HBeAg may be superior to serum HBsAg and HBV DNA as a clinical predictor of HBeAg seroconversion. At week 24, HBeAg level exceeding $2.0 \log _{10} \mathrm{~S} / \mathrm{CO}$ had a NPV of $92 \%$ in predicting sustained virological response, thus a solid stopping rule could be generated and applied [30].

\section{Nucleot(s)ide Therapy}

In large trails studying the efficacy of Lamivudine (LAM) in CHB patients, a daily dose of $100 \mathrm{mg}$ of LAM for 48 weeks was compared to $0.5 \mathrm{mg}$ of ETV. These studies showed that treatment with LAM in HBeAg-positive patients resulted in undetectable HBV DNA level in 36\%, HBV DNA suppression occurred by an average of $5.4 \log _{10}$ copies $/ \mathrm{ml}$, and $\mathrm{HBeAg}$ seroconversion in $18 \%$. In HBeAg-negative patients, undetectable HBV DNA occurred in $72 \%$, and HBV DNA suppression by an average of 4.5 $\log _{10}$ copies/ml [31, 32].

In another trails, CHB patients received 10mg/day of adefovir (ADV) for 48 weeks. ADV treatment suppressed HBV DNA by $3.5 \log _{10}$ copies/ml in HBeAgpositive patients and $3.9 \log _{10}$ copies/ml in HBeAgnegative patients, which was relatively slow. HBeAg 
seroconversion occurred less likely in only $12 \%$ of patients, and HBV DNA declined to undetectable level in only $21 \%$ of $\mathrm{HBeAg}$-positive patients and $51 \%$ of HBeAg-negative patients $[33,34]$.

Another study compared the efficacy of telbivudine (TBV) 600mg/day to LAM 100mg/day and showed that TBV was superior to LAM in lowering HBV DNA to undetectable level (60\% vs. $40 \%$ ), and in attaining improvement in the liver histology $(65 \%$ vs. $56 \%$ ) but not in ALT normalization (77\% vs. $75 \%$ ) or serological responses (HBeAg seroconversion in $23 \%$ vs. 22\%). In HBeAg-negative patients, TBV was superior to LAM in lowering HBV DNA to undetectable level ( $88 \%$ vs. $71 \%$ ), but not in reaching histological improvement (67\% vs. 66\%) or ALT normalization (74\% vs. $79 \%$ ). During the second year of treatment, these responses were well maintained, and at the end of year $2 \mathrm{HBeAg}$ seroconversion reached 30\% [35, 36].

Long term efficacy and safety of tenofovir disoproxil fumarate (TDF) monotherapy was studied in $347 \mathrm{HBeAg}$-negative and $238 \mathrm{HBeAg}$-positive patients after 48 weeks of double-blind comparison with adefovir [37] that entered open-label TDF for an additional 7 years. In the open-label evaluation analysis at week 144, HBV DNA < 400 copies/ $\mathrm{ml}$ was detected in $90 \%$ of $\mathrm{HBeAg}$-negative and 74\% HBeAg-positive patients. In HBeAg-positive patients, 34\% lost HBeAg and 26\% had HBeAg seroconversion. A durable 3 year viral suppression with TDF was shown by the data of this trail [38]. Moreover, the beneficial effect of long term suppression of replication of hepatitis B virus (HBV) with at least 5 years treatment with tenofovir on regression of advanced liver fibrosis was studied in 348 patients, of the 585 that had entered the open-label phase [38], with biopsy results at both baseline and week 240. During the 5 years, the proportion of patients with necroinflammation decreased; with increase in the proportion of participants with mild or no necroinflammation (Knodell range $0-3$ ) from $8 \%$ at baseline to $49 \%$ at year
1 and $80 \%$ at year 5. Improvement in the liver histology during the study was reflected by the distribution of Ishak scores that showed a progressive increase in the proportion with mild disease and decline in the proportion with severe disease. At baseline, 39\% of participants had no or mild fibrosis; which increased to $43 \%$ at year 1 and $63 \%$ at year 5 . On the contrary, 38\% had Ishak scores of 4 or more (pronounced bridging fibrosis to cirrhosis) at baseline, however it decreased to $28 \%$ at year 1 and $12 \%$ at year 5 . Overall, $87 \%$ of patients had histological improvement and $51 \%$ had documented fibrosis regression at year 5 . Moreover, patients with Ishak scores greater than 2 at baseline showed the highest degree of histological improvement (91\% or more) [39].

Another trail evaluated the safety and efficacy of ETV $(0.5 \mathrm{mg}$ ) in HBeAg-positive CHB patients treated for a minimum of 52 weeks $[40,41]$, and subsequently received open-label ETV in another rollover study for a cumulative total duration of up to 5 years. This study resulted in increasing proportions of patients achieving and maintaining HBV DNA $<300$ copies/ml with continuous treatment through years 3,4 , and 5 , thus occurring in $94 \%$ of patients at year 5. Moreover, HBeAg seroconversion occurred in $23 \%$ of the ETV long term cohort during the first trial, and in $31 \%$ of patients in the second study. These results proved the augmented benefits on serological response when ETV is given beyond 2 years [42].

Many studies have begun to show that lowering the HBV DNA level results in the reduction of hepatocellular carcinoma (HCC) risk in chronic HBV patients with or without cirrhosis [43, 44]. Consequently, a study was done to compare the incidence of HCC in 472 ETV treated patients and 1,143 non treated HBV patients (control group). Results revealed that the cumulative incidence rates of HCC in the matched ETV groups were $0.7 \%$ at year $2,1.2 \%$ at year $3,2.5 \%$ at year 4 , and $3.7 \%$ at year 5 , compared to $4 \%$ at year $2,7.2 \%$ 
at year $3,10 \%$ at year 4 , and $13.7 \%$ at year 5 in the matched control group. This study concluded that the development of HCC is efficiently suppressed with long term ETV treatment in chronically infected HBV patients [45].

\section{Nucleos(t)ide analogues in chronic HBeAg- Positive patients}

After occurrence of NUC-induced HBeAg seroconversion in HBeAg-Positive patients, therapy should be continued for an additional 12 months before stopping it; $40-80 \%$ of these patients are expected to maintain off-therapy durability of response $[13,46]$. Obviously, discrepancy in results and guideline recommendations regarding the durability of NUC-induced HBeAg seroconversion require elucidation. Therefore, the long term durability of NUC-induced HBeAg seroconversion was studied in a total of $132 \mathrm{HBeAg}$-positive patients who had received NA therapy during a median follow-up period of 5 years. The results showed an increase in the cumulative serological $(17 \%, 31 \%$, and $44 \%)$ and virologic recurrence rates (12\%, 42\%, and $50 \%$ ) at 1, 2, and 4 years respectively after NUC-induced HBeAg seroconversion. Overall, 70\% of patients showed either serologic or virologic recurrence leaving only a minority of patients with a durable remission after $\mathrm{HBeAg}$ seroconversion, whether on- or off treatment. Consequently, these findings concluded that treatment with NUC must be for a long term in HBeAg-positive patients after HBeAg seroconversion [47].

Another study evaluated the significance of ontreatment quantitative serum HBsAg level during NUC therapy as a strong predictor of sustained off treatment virological response (SVR: sustained inhibition of viral replication (HBV DNA level $<10,000$ $\mathrm{cp} / \mathrm{ml}$ ) until 6 months post treatment without reappearance of $\mathrm{HBeAg}$ ). It included 51 consecutive HBeAg-positive patients infected with genotype C who maintained HBeAg loss/seroconversion after at least 12 months of consolidation therapy. This study reached a cut-off level to predict SVR corresponding to a decline in HBsAg of $0.5 \log _{10} \mathrm{IU} / \mathrm{ml}$ or more at 6 months. Eight out of nine patients (88.9\%) who showed a decline in serum HBsAg level of $0.5 \log _{10} \mathrm{IU} / \mathrm{ml}$ or more maintained SVR (PPV: $88.9 \%)$. In contrast, no response occurred in $24(66.7 \%)$ of 36 patients who had a decrease in serum HBsAg of less than $0.5 \log _{10} \mathrm{IU} / \mathrm{ml}$ (NPV: $66.7 \%$ ) (Figure 2). Thus, on-treatment HBsAg level can be used in patients with HBeAg-positive chronic hepatitis B who achieved HBeAg loss/seroconversion during treatment to predict duration of therapy [48].

Figure 2: Fourth stopping rule: Entecavir/Tenofovir in HBeAg-positive patients

$$
\text { All patients } n=51
$$

PPV $88 \%$

$$
\text { Decline of HBsAg at month } 6
$$

NPV $64 \%$

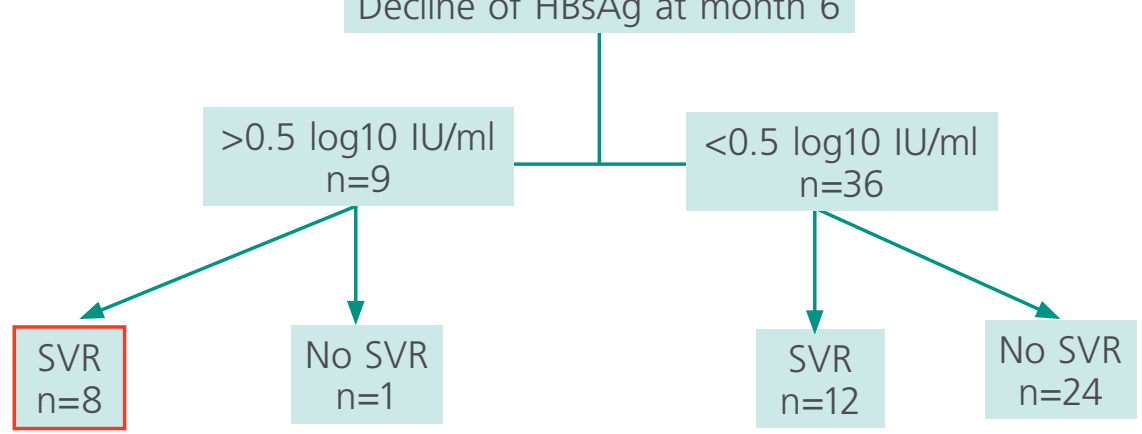




\section{Nucleos(t)ide analogues in chronic HBeAg- Negative patients}

Long term treatment with NUC is recommended in HBeAg-negative patients and HBeAg-positive patients who fail to seroconvert into anti-HBe, since they will less likely be able to achieve a sustained off treatment virological response [13]

In a prospective long term follow-up study, the rate of biochemical and virological responses, including HBsAg loss, was assessed in a cohort of 33 HBeAg-negative CHB patients after discontinuation of effective long term treatment (4 or 5 years) with adefovir dipivoxil (ADV). After ADV discontinuation, all patients completed a 5.5-year period of post treatment observation, with a median duration of 69 months. Sustained biochemical and virological remission was achieved in $18 \mathrm{pa}-$ tients (55\%) with 13 of them also clearing $\mathrm{HBsAg}$ (39\%). Thus, among patients with sustained biochemical and virological responses who stopped ADV treatment, 5.5-year rate of HBsAg clearance was $72 \%$. Therefore, these results showed that lower HBsAg level at end of treatment (EOT) could be used as a predictive marker for future HBsAg. Similarly, higher pretreatment and EOT ALT level were also associated with lower EOT HBsAg level and HBsAg loss [49].

The Asian Pacific Association for the Study of the Liver (APASL) guidelines recommended that in HBeAg-negative patients with undetectable HBV DNA level (confirmed on three separate occasions at least 6 months apart), treatment with NUCs can be discontinued [50]. Consequently, a study aimed to test this hypothesis in $95 \mathrm{HBeAg}$-negative CHB patients treated with ETV for 2 years. Results showed that within 1 year after stopping ETV therapy, clinical relapse occurred in $45 \%$ of patients. The only significant independent predictor for clinical relapse was the baseline HBV DNA $>2 \times 10^{5}$ or $5.3 \log _{10} \mathrm{IU} / \mathrm{ml}$. Clinical relapse occurred in $29 \%$ of the patients with a baseline serum HBV DNA $\leq 2$ $\times 10^{5}$ or $5.3 \log _{10} \mathrm{IU} / \mathrm{ml}$, as compared to $53.1 \%$ of those with HBV DNA $>2 \times 10^{5}$ or $5.3 \log _{10} \mathrm{IU} / \mathrm{ml}$. A longer consolidation therapy (>64 weeks) was associated with a much lower relapse rate $(28.6 \%$ versus $64.3 \%$ in those $<64$ weeks) and is specifically preferred for patients with higher baseline HBV DNA. Thus, the APASL guidelines stopping rule for HBeAg-negative CHB patients is adequate, provided that it is applied with proper off-therapy monitoring and adjusted to account for the baseline HBV DNA level [51].

\section{Conclusion}

Chronic hepatitis B patients with sustained inactive carrier state have a good prognosis without treatment. Durability of sustained off-therapy response occurred in $25-40 \%$ of patients after 12 months of therapy with PEG-IFN, and in 50\% of patients after several years of consolidation therapy with nucleos(t)ide analogues. In this review, we highlighted on the significance of HbsAg quantitation that was recently introduced into clinical practice, and showed its important role in prediction of sustained virological response in both $\mathrm{HBeAg}$ positive and negative CHB patients treated with either PEG-IFN or NUC and thus can be relied on in combination with HBV DNA and ALT levels to generate stopping rules. This will ultimately make a change in the different aspects of CHB treatment if interpreted correctly. Thus, further studies are needed to validate the precise role of HBsAg quantitation that could provide a guide for monitoring the antiviral response, detect the proper timing of stopping NUC therapy especially in HBeAg-negative CHB patients, and predict off treatment durability of highly potent NUC. Moreover, more trails that focus on the role of HBeAg quantitation must be done to reach the optimal road-map strategy in treating those difficult-to-cure population, hence avoiding many of the drugs costs and side effects and delivering the best care in terms of counseling, monitoring, and consequently reaching the most 
suitable therapy for each patient. Clinical studies addressing these issues seem to be highly needed in the future to use the results in our daily clinical practice.

\section{Author contributions}

$\mathrm{M} \mathrm{N}$ did the literature search and wrote the first draft, I I and R M polished the English language and edited the final manuscript.

\section{Competing Interests}

The authors declare that they have no competing interests.

\section{Acknowledgments}

No acknowledgments to dispense.

\section{References}

1. LeeWM. Hepatitis B virus infection. NEngl J Med 1997; 337: 1733 1745 [PMID: 9392700 DOI: 10.1056/ NEJM199712113372406]

2. Lavanchy D. Hepatitis B virus epidemiology, disease burden, treatment, and current and emerging prevention and control measures. J Viral Hepat 2004; 11: 97-107 [PMID: 14996343 DOI: 10.1046/j.1365-2893.2003.00487.x]

3. Liaw YF, Chu CM. Hepatitis B virus infection. Lancet 2009; 373: 582-592 [PMID: 19217993 DOI: 10.1016/S01406736(09)60207-5]

4. Block TM, Guo H, Guo JT. Molecular virology of hepatitis B virus for clinicians. Clin Liver Dis 2007; 11: 685-706 [PMID: 17981225 DOI: 10.1016/j.cld.2007.08.002]

5. Locarnini S, Zoulim F. Molecular genetics of HBV infection. Antivir Ther 2010; 15 Suppl 3: 3-14 [PMID: 21041899 DOI: 10.3851/IMP1619]

6. Doo EC, Ghany MG. Hepatitis B viriology for clinicians. Clin Liver Dis 2010; 14: 397-408 [PMID: 20638021 DOI: 10.1016/j. cld.2010.05.001]

7. Liaw YF, Chu CM. Hepatitis B virus infection. Lancet 2009; 373: 582-92 [PMID: 19217993 DOI: 10.1016/SO1406736(09)60207-5]

8. Hsu YS, Chien RN, Yeh CT, et al. Long-term outcome after spontaneous HBeAg seroconversion in patients with chronic hepatitis B. Hepatology 2002; 35: 1522-7 [PMID: 12029639 DOI: 10.1053/jhep.2002.33638]

9. Chu CM, Hung SJ, Lin J, Tai DI, Liaw YF. Natural history of hepatitis $B$ e antigen to antibody seroconversion in patients with normal serum aminotransferase levels. Am J Med 2004; 116: 829-34 [PMID: 15178498 DOI: 10.1016/j.amjmed.2003.12.040]
10. Liaw YF, Sheen IS, Chen TJ, Chu CM, Pao CC. Incidence, determinants and significance of delayed clearance of serum $\mathrm{HBsAg}$ in chronic hepatitis B virus infection: a prospective study. Hepatology 1991; 13: 627-31 [PMID: 2010157 DOI: 10.1002/ hep.1840130403]

11. $G$ Fattovich, N Olivari, M Pasino, M D'Onofrio, E Martone, F Donato. Long-term outcome of chronic hepatitis B in Caucasian patients: mortality after 25 years. GUT 2008; 57: 84-90 [PMID: 17715267 DOI: 10.1136/gut.2007.128496]

12. Lok AS, McMahon BJ. Chronic hepatitis B: update 2009. Hepatology 2009; 50: 661-662 [PMID: 19714720 DOI: 10.1002/ hep.23190]

13. European Association For The Study Of The Liver. EASL Clinical Practice Guidelines: Management of chronic hepatitis B virus infection. J Hepatol 2012; 57: 167-185 [PMID: 22436845 DOI: 10.1016/j.jhep.2012.02.010]

14. Brunetto MR, Oliviri F, Colombatto P, Moriconi F, Ciccorossi p, et al. Hepatitis B surface Antigen Serum Levels Help to Distinguish Active From Inactive Hepatitis B Virus Genotype D Carriers. Gastroenterology 2010; 139: 483-490 [PMID: 20451520 DOI: 10.1053/j.gastro.2010.04.052]

15. Martinot-Peignoux, Lapalus M, Laouenan C, Lada $O$, et al. Prediction of disease reactivation in asymptomatic hepatitis $B$ e antigen-negative chronic hepatitis B patients using baseline serum measurements of HBsAg and HBV-DNA. Journal of Clinical Virology 2013; 58: 401-407 [PMID:24004660 DOI: 10.1016/j.jcv.2013.08.010]

16. Marcellin P, Lau GK, Bonino F, Farci P, Hadziyannis S, et al. Peg interferon Alfa-2a Alone, Lamivudine Alone, and the Two in Combination in Patients with $\mathrm{HBeAg}$-Negative Chronic Hepatitis B. N Engl J Med 2004; 351: 1206-1217 [PMID: 15371578 DOI: 10.1056/NEJMoa040431]

17. Marcellin P, Bonino F, Lau GK, Farci P, Yurdaydin C, et al. Sustained Response of Hepatitis B e Antigen-Negative Patients 3 Years After Treatment with Peg interferon Alfa-2a. Gastroenterology 2009; 136: 2169-2179 [PMID: 19303414 DOI: 10.1053/j.gastro.2009.03.006]

18. Marcellin P, Bonino F, Yurdaydin C, Hadziyannis S, Moucari R, et al. Hepatitis B surface antigen levels: association with 5-year response to peg interferon alfa-2a in hepatitis $B$ e-antigennegative patients. Hepatol Int. 2013; 7: 88-97 [PMID: 23518903 DOI: 10.1007/s12072-012-9343-x]

19. Brunetto MR, Moriconi F, Bonino F, Lau GK, Farci $P$, et al. Hepatitis $B$ virus surface antigen levels: A guide to sustained response to peg interferon alfa-2a in $\mathrm{HBeAg}$-negative chronic hepatitis B. Hepatology 2009; 49: 1141-1150 [PMID: 19338056 DOI: 10.1002/hep.22760]

20. Moucari R, Mackiewicz V, Lada O, Ripault MP, Castelnau C, et al. Early Serum HBsAg Drop: A Strong Predictor of Sustained Virological Response to Pegylated Interferon Alfa-2a in HBeAgNegative Patients. Hepatology 2009; 49: 1151-1157 [PMID: 19115222 DOI:10.1002/hep.22744] 
21. Rijckborst $V$, Hansen $B E$, Cakaloglu $Y$, Ferenci $P$, et al. Early ontreatment prediction of response to peg interferon alfa-2a for HBeAg-negative chronic hepatitis B using HBsAg and HBV DNA levels. Hepatology 2010; 52: 454-461 [PMID: 20683945 DOI: 10.1002/hep.23722]

22. Rijckborst $V$, Hansen $B E$, Ferenci $P$, Brunetto $M R$, et al. Validation of a stopping rule at week 12 using HBsAg and HBV DNA for $\mathrm{HBeAg-negative} \mathrm{patients} \mathrm{treated} \mathrm{with} \mathrm{peg} \mathrm{interferon} \mathrm{alfa-2a.} \mathrm{J}$ Hepatol 2012; 56: 1006-1011 [PMID: 22245886 DOI: 10.1016/j. jhep.2011.12.007]

23. Fattovich G, Rugge M, Brollo L, Pontisso P, Noventa F, et al. Clinical, virologic and histologic outcome following seroconversion from $\mathrm{HBeAg}$ to anti-HBe in chronic hepatitis B. Hepatology 1986; 6: 167-72 [PMID: 3957228 DOI:10.1002/1840060203]

24. Niederau C, Heintges T, Lange S, Goldmann G, Niederau CM, et al. Long-term follow-up of HBeAg-positive patients treated with interferon alfa for chronic hepatitis B.N Engl J Med 1996; 334: 1422-7 [PMID: 8618580 DOI: 10.1056/NEJM199605303342202]

25. Lau GKK, Piratvisuth T, Luo KX, Marcellin P, Thongsawat S, et al. Peg interferon Alfa-2a, Lamivudine, and the Combination for HBeAg-Positive Chronic Hepatitis B. N Engl J Med 2005; 352: 2682-95 [PMID: 15987917 DOI: 10.1056/NEJMoa043470]

26. Liaw YF, Jia JD, Chan HLY, Han KH, Tanwandee T, et al. Shorter Durations and Lower Doses of Peg interferon alfa-2a Are Associated with Inferior Hepatitis B e Antigen Seroconversion Rates in Hepatitis B Virus Genotypes B or C. Hepatology 2011; 54: 1591-1599 [PMID: 22045673 DOI:10.1002/hep.24555]

27. Buster EH, Flink HJ, Cakaloglu Y, Simon K, Trojan J, et al. Sustained HBeAg and HBsAg Loss After Long Term Follow-up of HBeAg-Positive Patients Treated With Peg interferon alpha-2b. Gastroenterology 2008; 135: 459-467 [PMID: 18585385 DOI: 10.1053/j.gastro.2008.05.031]

28. Sonneveld MJ, Hansen BE, Piratvisuth T, Jia JD, Zeuzem S, et al. Response-Guided Peg interferon Therapy in Hepatitis B e Antigen-Positive Chronic Hepatitis B Using Serum Hepatitis B surface Antigen Levels. Hepatology 2013; 58: 872-880 [PMID: 23553752 DOI:10.1002/hep.26436]

29. Heijtink RA, Kruining J, Honkoop P, Kuhns MC, Hop WC, et al. Serum $\mathrm{HBeAg}$ quantitation during antiviral therapy for chronic hepatitis B. J. Med. Virol. 1997; 53: 282-287 [PMID: 9365897 DOI: 10.1002/(SICI)1096-9071(199711)53:3<282::aidjmv18>3.0.CO;2-J]

30. Tangkijvanich $P$, Komolmit $P$, Mahachai $V$, Sanguanmoo $P_{1}$ Theamboonlers A, Poovorawan $Y$. Comparison between quantitative hepatitis B surface antigen, hepatitis B e-antigen and hepatitis B virus DNA levels for predicting virological response to pregylated interferon alpha-2b therapy in hepatitis $\mathrm{B}$ e-antigen-positive chronic hepatitis B. Hepatology Research 2010; 40: 269-277 [PMID: 20070399 DOI: 10.1111/ j.1872034X.2009.00592.x]
31. Chang TT, Gish RG, de Man R, Gadano A, Sollano J, Chao YC, et al. A comparison of entecavir and lamivudine for HBeAgpositive chronic hepatitis B. N Engl J Med. 2006; 354(10): 100110 [PMID: 16525137 DOI:10.1056/NEJMoa051285]

32. Lai CL, Shouval D, Lok AS, Chang TT, Cheinquer H, Goodman $Z$, et al. Entecavir versus lamivudine for patients with HBeAgnegative chronic hepatitis B. N Engl J Med. 2006; 354(10): 101120 [PMID: 16525138 DOI: 10.1056/NEJMoa051287]

33. Marcellin P, Chang TT, Lim SG, Tong MJ, Sievert W, Shiffman $\mathrm{ML}$, et al. Adefovir dipivoxil for the treatment of hepatitis $\mathrm{B}$ e antigen-positive chronic hepatitis B. N Eng/ J Med. 2003; 348(9): 808-16 [PMID: 12606735 DOI:10.1056/NEJMoa020681]

34. Hadziyannis SJ, Tassopoulos NC, Heathcote EJ, Chang TT, Kitis G, Rizzetto M, et al. Adefovir dipivoxil for the treatment of hepatitis B e antigen-negative chronic hepatitis B. N Engl J Med. 2003; 348(9): 800-7 [PMID: 12606734 DOI:10.1056/NEJMoa021812]

35. Lai CL, Gane E, Liaw YF, Hsu CW, Thongsawat S, Wang Y, et al. Telbivudine versus lamivudine in patients with chronic hepatitis B. N Engl J Med. 2007; 357(25): 2576-88 [PMID: 18094378 DOI: 10.1056/NEJMoa066422]

36. Liaw YF, Gane E, Leung N, Zeuzem S, Wang Y, Lai CL, et al. 2-Year GLOBE trail results: telbivudine Is superior to lamivudine in patient with chronic hepatitis B. Gastroenterology 2009; 136(2): 486-95 [PMID: 19027013 DOI:10.1053/j.gastro.2008.10.026]

37. Marcellin P, Heathcote EJ, Buti M, Gane E, de Man RA, et al. Tenofovir disoproxil fumarate versus adefovir dipivoxil for chronic hepatitis B. N Engl J Med 2008; 359: 2442-55 [PMID: 19052126 DOI:10.1056/NEJMoa0802878]

38. Heathcote EJ, Marcellin P, Buti M, Gane E, de Man RA, et al. Three-Year Efficacy and Safety of Tenofovir Disoproxil Fumarate Treatment for Chronic Hepatitis B. Gastroeneterology 2011; 140: 132-143 [PMID: 20955704 DOI:10.1053/j.gastro.2010.10.011)

39. Marcellin $P$, Gane E, Buti M, Afdhal N, Sievert W, et al. Regression of cirrhosis during treatment with tenofovir disoproxil fumarate for chronic hepatitis B: a 5-year open-label follow-up study. Lancet 2013; 381: 468-75 [PMID: 23234725 DOI:10.1016/ S0140-6736(12)61425-1]

40. Chang TT, Gish RG, de Man RA, Gadano A, Sollano J, et al. A comparison of entecavir and lamivudine for HBeAg-positive chronic hepatitis B. N Eng J Med 2006; 354: 1001-1010 [PMID: 16525137 DOI: 10.1056/NEJMoa051285]

41. Gish RG, Lok AS, Chang TT, de Man RA, Gadano A, Sollano J, et al. Entecavir therapy for up to 96 weeks in patients with HBeAgpositive chronic hepatitis B. Gastroenterology 2007; 133: 14371444 [PMID: 17983800 DOI:10.1053/j.gastro.2007.08.025]

42. Chang TT, Lai CL, Kew Yoon S, Lee SS, Coelho HS, et al. Entecavir treatment for up to 5 years in patients with hepatitis B e antigen-positive chronic hepatitis B. Hepatology 2010; 51: 422-430 [PMID: 20049753 DOI:10.1002/hep.23327]

43. Liaw YF, Sung JJY, Chow WC, Farrell G, Lee CZ, Yuen $H$, et al. Lamivudine for patients with chronic hepatitis $\mathrm{B}$ and advanced liver disease. N Engl J Med 2004; 351: 1521-1531 [PMID: 15470215 DOI: 10.1056/NEJMoa033364] 
44. Matsumoto A, Tanaka E, Rokuhara A, Kiyosawa K, Kumada $H$, Omata $M$, et al. Efficacy of lamivudine for preventing hepatocellular carcinoma in chronic hepatitis B: a multicenter retrospective study of 2795 patients. Hepatol Res 2005; 32: 173-184 [PMID: 16024289 DOI: 10.1016/j.hepres.2005.02.006]

45. Hosaka T, Suzuki F, Kobayashi M, Seko Y, Kawamura Y, Sezaki $\mathrm{H}$, et al. Long term Entecavir treatment reduces hepatocellular carcinoma incidence in patients with hepatitis B virus infection. Hepatology 2013; 58: 98-107 [PMID: 23213040 DOI: 10.1002/ hep.26180]

46. Lok AS, McMahon BJ. Chronic hepatitis B. Hepatology 2007; 45: 507-539 [PMID: 17256718 DOI: 10.1002/hep.21513]

47. Reijnders JGP, Perquin MJ, Zhang $N$, Hansen BE, Janssen $H L$. Nucleos(t)ide analogues only induce temporary hepatitis $B$ e antigen seroconversion in most patients with chronic hepatitis B. Gastroenterolgy 2010; 139: 491-498 [PMID: 20381492 DOI:10.1053/j.gastro.2010.03.059]

48. Kim SS, Lee D, Lee MH, Cheong JY, Cho SW. Association of ontreatment serum hepatitis B surface antigen level with sustained virological response to nucleos(t)ide analog in patients with hepatitis B e-antigen positive chronic hepatitis B. Hepatology Research 2013; 43 :219-227 [PMID: 22835015 DOI:10.1111/ j.1872-034X.2012.01065.x]

49. Hadziyannis SJ, Sevastianos V, Rapti I, Vassilopoulos D, Hadziyannis E. Sustained responses and loss of HBsAg in HBeAgnegative patients with chronic hepatitis B who stop long-term treatment with adefovir. Gastroenterology 2012; 143: 629-636 [PMID: 22659218 DOI:10.1053/j.gastro.2012.05.039]

50. Liaw YF, Kao JH, Piratvisuth T, Chan HLY, Chien RN, Liu CJ, et al. Asian-Pacific consensus statement on the management of chronic hepatitis B: a 2012 update. Hepatol Int 2012; 6: 531-561 [DOI: 10.1007/s12072-012-9365-4]

51. Jeng WJ, Sheen IS, Chen YC, Hsu CW, Chien RN, Chu CM, Liaw YF. Off-therapy durability of response to entecavir therapy in hepatitis B e antigen-negative chronic hepatitis B patients. Hepatology 2013; 58: 1888-1896 [PMID: 23744454 DOI: 10.1002/hep.26549]

\section{Comment on this article:}

\section{$f(B)$ in $8+S P$}

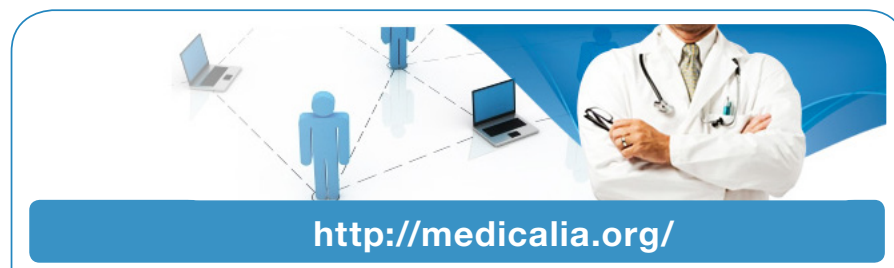

Where Doctors exchange clinical experiences, review their cases and share clinical knowledge. You can also access lots of medical publications for free. Join Now!

\section{Publish with iMedPub}

\section{http://www.imed.pub}

International Archives of Medicine is an open access journal publishing articles encompassing all aspects of medical science and clinical practice. IAM is considered a megajournal with independent sections on all areas of medicine. IAM is a really international journal with authors and board members from all around the world. The journal is widely indexed and classified Q1 in category Medicine. 